\title{
Erratum to: Isolation of 15 new polymorphic microsatellite markers from the blue-spine unicornfish Naso unicornis
}

John B. Horne • Jennifer L. McIlwain • Lynne van Herwerden

Published online: 13 February 2010

(C) Springer Science+Business Media B.V. 2010

Erratum to: Conservation Genet Resour

DOI 10.1007/s12686-009-9129-1

The Genbank accession numbers omitted from Table 1 footnote are-GU189390-GU189404.

The online version of the original article can be found under doi:10.1007/s12686-009-9129-1.

J. B. Horne $(\bowtie) \cdot$ L. van Herwerden

School of Tropical and Marine Biology, Molecular Ecology and Evolution Laboratory, James Cook University, Townsville,

QLD 4811, Australia

e-mail: john.horne@jcu.edu.au

J. L. McIlwain

Marine Laboratory, University of Guam, Mangilao,

GU 96923, USA 